\title{
$\begin{array}{llllllllllllllllllllllll}P & R & Z & E & G & L & A & D & Z & A & C & H & O & D & N & I & O & P & O & M & O & R & S & K\end{array}$ ROCZNIK XXXIV (LXIII) ROK 2019 ZESZYT 2
}

\author{
RAdOSŁAW PTASZYŃSKI \\ ORCID: 0000-0001-7508-0496 \\ Uniwersytet Szczeciński, Wydział Humanistyczny \\ e-mail: radoslaw.ptaszynski@gmail.com \\ Magdalena ŻUKOWSKA \\ ORCID: 0000-0001-8360-7892 \\ Pomorski Uniwersytet Medyczny (studia doktoranckie) \\ e-mail: zukowskalena@gmail.com
}

\section{BolesŁaW Nagay (1926-2014). SZKIC DO PORTRETU CHIRURGA}

Słowa kluczowe: medycyna, Szczecin, biografia, Bolesław Nagay Keywords: medicine, Szczecin, biography

Wielkie przeobrażenia powojenne oznaczały dla Pomorza Zachodniego nie tylko wymianę ludności, ale także konieczność budowy od podstaw nowych instytucji życia społecznego. Dotyczyło to również nauki, a nie byłoby to możliwe bez napływu inteligencji, która zanim urodziło się i wykształciło nowe pokolenie, rozpoczęła budowę polskiej kultury, oświaty i nauki na nowo pozyskanych terenach. Ze względu na straty wojenne, ale i czarną legendę Pomorza rysującego się jako miejsce niebezpieczne, bez tradycji uniwersyteckich, pozyskanie kadry, która chciałaby się osiedlić i pracować w Szczecinie, nie było łatwe. Czasem decydował przypadek, czasem działania władz, niemniej już w pierwszych latach 
powojennych udało się uruchomić Akademię Handlową (październik 1946 r.) i Akademię Lekarską (marzec 1948 r.)ํ.

O ile historia rozwoju instytucjonalnego nauki na Pomorzu Zachodnim wydaje się dość dobrze rozpoznana przez badaczy, to istotnym brakiem wydaje się spojrzenie na te zagadnienia z użyciem metod współczesnej biografistyki². Celem artykułu jest zatem przedstawienie szkicu biograficznego Bolesława Nagaya - jednej z wybitnych postaci szczecińskiej medycyny, nauczyciela całego pokolenia szczecińskich chirurgów, światowej klasy specjalisty chirurgii ręki.

Urodził się 27 stycznia 1926 roku we Lwowie. Jego ojcem był Stanisław Nagay, a matką Balbina Hess. Trudno dziś ustalić dokładne drzewo genealogiczne i pochodzenie nazwiska - brzmienie wskazywać może na tatarski rodowód. Rodzina mogła pozwolić sobie na pomoc domową (Filomena Birek), choć nie była szczególnie majętna, jako że utrzymywała się wyłącznie z pracy ojca zatrudnionego w magazynach Związku Ekonomicznych Kółek Rolniczych (później w Państwowej Szkole Ogrodniczej). Mieszkali we Lwowie, w oficynie kamienicy przy ul. Adama Mickiewicza 22 (obecnie Łyśtopadowoho czynu), należącej do stomatologa Salomona Bunda, nieopodal ogrodu jezuickiego, soboru św. Jura i gmachu Dyrekcji PKP. Bolesław miał jeszcze dwie siostry - Bogusławę i Irenę, wraz z nimi mieszkała także ciotka Sabina. W kamienicy przebywały rodziny polskie, żydowskie i ukraińskie. Z tego okresu Nagay zapamiętał m.in. dobre, przyjacielskie kontakty z Ukraińcami, ale i przechodzącą ulicą Mickiewicza, rozpędzoną przez policję, demonstrację Ukraińców domagających się autonomii³

1 L. Janiszewski, H. Lesiński, Rola i osiagnięcia nauk humanistycznych w procesach integracyjnych i kulturowych Pomorza Zachodniego w latach 1945-1985, w: Udziat nauki i szkolnictwa wyższego w rozwoju Pomorza Zachodniego w latach 1945-1985, red. H. Lesiński, Szczecin 1986, s. 186-206; Nauka polska na Pomorzu Szczecińskim 1946-1956-1976: materiały z sesji naukowej zorganizowanej przez Szczecińskie Towarzystwo Naukowe w ramach obchodów XX-lecia STN i XXX-lecia powstania szkolnictwa wyższego w Szczecinie, red. H. Lesiński, Szczecin 1979; Dwudziestolecie nauki polskiej na Pomorzu Szczecińskim 1946-1966, red. L. Babiński, H. Lesiński, Szczecin-Poznań 1968; H. Lesiński, Rozwój nauki i szkolnictwa wyższego w Szczecinie, „Przegląd Zachodniopomorski” 1975, z. 3-4; T. Ślepowroński, Polska i wschodnioniemiecka historiografia Pomorza Zachodniego 1945-1970, Szczecin 2008, s. 224-225 (mps w zbiorach autorów); Od Akademii Lekarskiej w stronę Uniwersytetu Medycznego: instytucja, red. J. Kojder, Szczecin 2008; Powstawanie uczelni medycznej na Pomorzu Zachodnim: historia nauczania dziedzin medycyny w Pomorskiej Akademii Medycznej, red. J. Kojder, Szczecin 2008.

2 Szerzej: T. Rzepa, J. Leoński, Szkice do portretów, Węgrowiec 1994, s. 9-12; tychże, O biografii i metodzie biograficznej, Poznań 1993, s. 25.

3 B. Nagay, Wspomnienia starego chirurga, mps udostępniony przez Leszka Nagaya. 
Dzieciństwo Bolesława nie odbiegało niczym od losów jego rówieśników uczęszczał do szkoły i zajmował się rzeczami typowymi dla dorastających chłopców. Dorabiał, udzielając korepetycji kolegom.

Przełomem, który zmienił życie całego pokolenia, był oczywiście wrzesień 1939 roku. Tuż przed wybuchem wojny, razem z grupą rówieśników, Nagay otrzymał ważne zadanie, miał zajmować się „specyficzną” obroną przeciwlotniczą wypatrywaniem wrogich samolotów. Pierwszy nalot bombowy na miasto, mimo narastającego napięcia, był jednak dla mieszkańców zaskoczeniem. W wyniku bombardowania zapaliła się frontowa część kamienicy, rodzina musiała schronić się w piwnicach budynku Dyrekcji PKP. Również wejście do miasta Armii Czerwonej zdezorientowało lwowian, ze względu na ograniczony dopływ informacji spodziewano się raczej Niemców. Władze radzieckie zgodziły się na ponowne uruchomienie szkół, zmieniając część kadry i wprowadzając do placówek komisarzy politycznych. W takich warunkach Bolesław Nagay kontynuował naukę. Szkoła organizowała także dożywianie dzieci, była to wprawdzie tylko kromka chleba z marmoladą i szklanka herbaty, jednak w tamtych warunkach miało to istotne znaczenie.

Tej pierwszej zimy okupacji szczególnie dokuczał rodzinie brak opału i żywności. Rozpoczęły się także wywózki Polaków w głąb ZSRR. Z tego czasu Nagay zapamiętał zbliżenie między Polakami a Ukraińcami, które zobrazował anegdotą - w ogromnej kolejce do sklepu z żywnością, w pewnym momencie ukraiński ekspedient wezwał swoich rodaków do ustąpienia pierwszeństwa Polakom, ze względu na zbliżanie się świąt katolickich ${ }^{4}$. W tym czasie też Bolesław nawiązał kontakty z rówieśnikami Rosjanami - dziećmi urzędników kolejowych.

29 czerwca 1941 roku to nowy rozdział w historii Lwowa - wejście do miasta Niemców. Kilka dni wcześniej do domu Nagayów dotarł przerażająco wyniszczony uciekinier z więzienia Brygidek, który opowiedział o masowych mordach dokonywanych przez NKWD (sam nie jadł blisko 30 dni i prosił o niepokazywanie mu jedzenia). Okupacja niemiecka przyniosła chwilową nadzieję na złagodzenie terroru i niepokoju wynikającego z entuzjazmu ukraińskich mieszkańców miasta. Nadal jednak utrzymywał się bardzo dotkliwy niedostatek żywności, przydział chleba wynoszący jeden kilogram na tydzień oznaczał, że mieszkańcy stanęli przed klęską głodu. Ratunkiem dla rodziny Bolesława było znalezienie przez niego zatrudnienia w piekarni (wynagrodzenie wynosiło kilogram chleba dziennie).

\footnotetext{
4 Tamże.
} 
Ponownie wrócił do szkoły, tym razem była to szkoła handlowa z polskim językiem nauczania, uzupełniał też edukację na tajnych kompletach. W 1943 roku niemal cudem uciekł SS-manowi w czasie łapanki, to doświadczenie przekonało go, że musi poszukać pracy, która dawałaby jak najlepszy Ausweis. Dzięki znajomościom sióstr został zatrudniony w Instytucie Beringa, jednostka ta zajmowała się stworzeniem i produkcją szczepionki przeciwko tyfusowi, nazywanego też durem plamistym lub osutkowym ${ }^{5}$.

W XX wieku ta choroba zakaźna dziesiątkowała ludzkość Europy. Tylko podczas I wojny światowej zachorowało trzydzieści do czterdziestu milionów osób, a zmarło około trzech milionów. Ludwik Hirszfeld wspominał, że „Epidemia stała się prawdziwym biczem bożym, wyludniając doszczętnie wsie i miasta" jest przez wszy odzieżowe (odkrycia dokonał w 1909 r. francuski bakteriolog Charles Nicolle ${ }^{7}$ ), nie znano sposobu zapobiegania nowym zachorowaniom, a walka z chorobą polegała jedynie na gaszeniu powstałych już jej ognisk. Nie ograniczało to jednak epidemii. Badania nad riketsjami, wszami i durem plamistym prowadził biolog, prof. Rudolf Weigl ${ }^{8}$. Ten lwowski uczony wynalazł metodę hodowli wszy zakażonych zarazkiem tyfusowym i jako pierwszy na świecie otrzymał szczepionkę przeciwko tyfusowi plamistemu. Był to przełom w badaniach nad opanowaniem panującej wówczas epidemii i stąd szczególna waga lwowskiego Instytutu?.

Jednostkę tę w kolejnych latach rozbudowywano, także po 1939 roku jej celem była produkcja szczepionki na potrzeby kolejno okupujących Lwów Sowietów i Niemców. Pracownicy zatrudnieni we lwowskim Instytucie brali udział $\mathrm{w}$ poszczególnych etapach powstawania szczepionki, a jednym z nich było

5 To choroba zakaźna wywoływana przez bakterie Rickettsia prowazekii atakujące głównie układ nerwowy, naczynia krwionośne, gruczoły dokrewne oraz serce.

6 Zwyciężý tyfus: Instytut Rudolfa Weigla we Lwowie: dokumenty i wspomnienia, red. Z. Stuchly, Wrocław 2001.

7 Charles Nicole (1886-1936), lekarz, bakteriolog, laureat Nagrody Nobla 1928 r. za doświadczalne udowodnienie, że dur plamisty przenoszony jest na człowieka przez wszy odzieżowe.

8 Rudolf Stefan Jan Weigl (1883-1957), biolog, twórca pierwszej skutecznej szczepionki przeciw tyfusowi plamistemu, kilkakrotnie nominowany do Nagrody Nobla; profesor Uniwersytetu Jana Kazimierza we Lwowie, Uniwersytetu Jagiellońskiego i Uniwersytetu im. Adama Mickiewicza w Poznaniu; Sprawiedliwy wśród Narodów Świata.

9 W 1920 r. w jednym ze skrzydeł gmachu Uniwersytetu Jana Kazimierza we Lwowie utworzono Instytut Badań nad Tyfusem Plamistym i Wirusami prof. Weigla; Prof. dr. Rudolf Weigllaureatem miasta Lwowa, „Gazeta Lwowska” 1937, nr 14, 20 I. 
karmienie wszy ludzką krwią. Karmiciel gumową taśmą mocował sobie do nogi niewielkie drewniane klateczki wielkości pudełka od zapałek zamieszkiwane przez około 600 wszy odżywiających się krwią właściciela przez blisko $45 \mathrm{~min}$ dziennie. Za swoją pracę otrzymywał niewielką zapłatę, która uzależniona była od ilości przymocowanych do nogi klatek ${ }^{10}$. Nagay w pewnym okresie miał takich klatek 12, co oznaczało 7 tys. wszy ${ }^{11}$. Było to jego pierwsze spotkanie z medycyną. Co istotne, praca w instytucie dawała praktycznie nietykalność ze strony okupantów.

Niestety z powodu młodego wieku i nieodpowiedniej diety po trzech miesięcach zachorował na anemię, którą wyleczył dzięki pomocy Bronisława Duchowicza, emerytowanego profesora politechniki zajmującego się ziołolecznictwem ${ }^{12}$. Po powrocie do zdrowia, trzymiesięcznym przeszkoleniu i pięciu specjalnych szczepieniach ponownie podjął pracę w laboratorium, teraz jako wykwalifikowany laborant-strzykacz na oddziale zakaźnym. Praca dawała dobry zarobek i nietykalność ze strony Niemców, którzy bali się zakażenia tyfusem. Także napis na drzwiach mieszkania „Wstęp tylko na własną odpowiedzialność - niebezpieczeństwo zakażenia" trzymał ich z daleka, co z kolei umożliwiało rozwinięcie działalności konspiracyjnej.

W 1942 roku Nagay został zaprzysiężony i rozpoczął działalność w drużynie Trzaski (Marka Zakrzewskiego). Używał pseudonimów „Lach” i „Leopold”. Początkowo działalność konspiracyjna ograniczała się do teoretycznych zajęć wojskowych, zapoznaniu z bronią, zasadach walki w mieście, obserwacji obiektów, później przygotowań do zdobycia miasta w ramach akcji „Burza”.

W tym samym roku rodzina Nagayów została przez władze przesiedlona do domu przy ul. Odrowąża, niestety wiosną 1944 dom ten został trafiony radziecką bombą, co wymusiło kolejną przeprowadzkę - do kamienicy przy pl. Zofii. Gdy Bolesław wrócił po produkty żywnościowe do domu na Odrowąża, spotkał radzieckiego żołnierza, który strzelił do niego z odległości około 150 m, na szczęście chybiając. Dało mu to szansę na ucieczkę, ale i stało się zapamiętanym na całe

${ }^{10}$ A. Allen, Fantastyczne laboratorium Doktora Weigla. Lwowscy uczeni, tyfus $i$ walka z Niemcami, Wołowiec 2016; Zwyciężyć tyfus..., s. 14.

11 Wykaz osób zatrudnionych w Instytucie prof. Rudolfa Weigla w latach niemieckiej okupacji Lwowa (lipiec 1941 - lipiec 1944), http://lwow.eu/weigl/weiglowcy2013.pdf (dostęp 6.06.2017).

12 Bronisław Duchowicz (1876-1952), chemik i mineralog; działacz oświatowy i abstynencki; nauczyciel i wykładowca akademicki; dyrektor Szkoły Realnej w Rawie Ruskiej, w Żywcu i VIII Gimnazjum we Lwowie; członek Rady Szkolnej Krajowej, krajowy inspektor szkolny. 
życie doświadczeniem. W tym też czasie jako młody partyzant miał przeprowadzić oddział AK z pl. Smolki (obecnie pl. gen. Hryhorenki) do śródmieścia. Niestety grupa ta po znalezieniu sklepu z alkoholem nie „nadawała się” już ani do marszu, ani do walki. Kilka dni później, gdy szedł na miejsce zbiórki, został zatrzymany przez staruszkę, która poinformowała go o aresztowaniu kolegów. Uciekł i jak wspominał, tak zakończyła się ,,walka uliczna w ramach akcji «Burza»"13. Następnie przyszła rejestracja poborowych przez nowe władze - radziecki oficer poszukiwał mówiących po rosyjsku, Nagay zgłosił się i został zatrudniony w biurze wojskowym. Zajmował się tam wypisywaniem powołań do wojska i przepisywaniem komunikatów, w ten sposób, ku swojemu zadowoleniu, nie został wysłany na front. W miarę możliwości mógł wówczas ostrzegać kolegów przed nadchodzącym powołaniem do wojska, co dawało im czas na ucieczkę. Praca ta była bezpłatna, zgłosił się więc do dawnego Instytutu Behringa, przemianowanego na San Bak Instytut, którym kierował uczeń Weigla, nieprzeciętny uczony, a później także duchowny Henryk Mosing ${ }^{14}$. Nagay otrzymał wówczas posadę dozorcy nocnego. Po komisji lekarskiej, na której otrzymał kategorię zwalniającą ze służby liniowej, opuścił biuro wojskowe i w instytucie podjął pracę na stanowisku laboranta-strzykacza i karmiciela ${ }^{15}$.

Mniej więcej rok wcześniej, jak wspomina sam Nagay, pomyślał o tym, aby zostać lekarzem. Impulsem była śmierć jego siostry Bogusławy, która także pracowała w instytucie i zmarła na tyfus, mając zaledwie 23 lata.

Wraz ze zbliżaniem się końca wojny Bolesław podjął naukę w klasie maturalnej zorganizowanej w spartańskich warunkach przez Adama Wągiera i Ludwika Bazylowa (w szkole nr 34). Klasa ta została zorganizowana z kilku roczników polskich dzieci, wcześniej uczęszczających zazwyczaj na tajne komplety. Nagay także w nich uczestniczył, a jego nauczycielami byli m.in. Jan i Franciszek Harhalowie, Stanisław Umański, Józef Zdąbłasz. W klasie utworzonej przez Węgiera próbowano przygotować młodzież w ekspresowym tempie do egzaminu maturalnego. Plan zakładał zrealizowanie programu jednej klasy w ciągu miesiąca.

${ }^{13}$ B. Nagay, Wspomnienia..., k. 19.

${ }^{14}$ Późniejsza nazwa to Lwowski Instytut Epidemiologii, Mikrobiologii i Higieny. Od sierpnia 1944 do czerwca 1946 r. zatrudnionych tam było ok. 150 osób, wyłącznie Polaków. Po repatriacji pozostało w tej jednostce ok. 20 osób.

Henryk Mosing (1910-1999), lekarz, epidemiolog, kapłan, uczeń oraz bliski współpracownik profesora Rudolfa Weigla. Bolesław Nagay i syn Leszek odwiedzili Mosinga we Lwowie w końcu lat 90., świadcząc mu pomoc medyczną po wylewie.

${ }^{15}$ B. Nagay, Wspomnienia..., k. 14, 20. 
Egzamin maturalny odbył się w sierpniu 1945 roku (obowiązkowy egzamin z rosyjskiego uczniowie zdali dzięki wsparciu prof. Ludwika Bazylowa ${ }^{16}$, który przekonał nauczycielkę rosyjskiego do przymknięcia oka na braki abiturientów w tym zakresie) $)^{17}$.

W końcu sierpnia 1945 roku Nagay wyjechał z rodzinnego miasta razem z transportem Teatru Polskiego, w którym pracowała ciotka Sabina. Uważał, że musi uciekać, bowiem wielu kolegów z dawnego oddziału AK zostało aresztowanych. Ojciec sprzedał mieszkanie za 1500 rubli, co starczyło na kilkanaście bochenków chleba. Rodzina przybyła początkowo do krewnych w Rozwadowie, by następnie udać się do Gdyni, gdzie był już szwagier Bolesława. Nagay początkowo planował rozpocząć studia na Politechnice (Wydział Chemii), jednak okazało się, że lista jest już definitywnie zamknięta. Na korytarzu spotkał wówczas kolegę ze Lwowa, który znał dr. Ziemnowicza, neurochirurga, ten zaś wpisał go na listę kandydatów na studia medyczne pod numerem 875 (planowano przyjąć 200 osób). Egzamin wstępny w tym szczególnym roczniku polegał na opisaniu osobistości światowej nauki i zakończył się dla niego sukcesem. Nagay rozpoczął studia na Wydziale Lekarskim Akademii Medycznej w Gdańsku. W tym też czasie wstąpił do młodzieżowej organizacji PSL Stanisława Mikołajczyka ZWM „Wici”, zostając przewodniczącym koła akademickiego organizacji. W czerwcu 1948 roku ożenił się z pochodzącą z Wilna, również studentką medycyny, Kamilą Pawlak. Ze związku tego narodziło się trzech synów (Zbigniew, Tomasz i Leszek).

Dopiero w Gdańsku, na pierwszym roku studiów, obserwując chirurgów podczas operacji, zrozumiał, że chce zając się tą dziedziną ${ }^{18}$. Po uzyskaniu absolutorium (w 1950 r.), ale jeszcze przed zaliczeniem siedmiu egzaminów dyplomowych, otrzymał pracę jako zastępca młodszego asystenta w I Klinice

\footnotetext{
${ }^{16}$ Ludwik Bazylow (1915-1985), historyk, absolwent UJK we Lwowie, wykładowca Uniwersytetu Warszawskiego i Uniwersytetu Wrocławskiego; kierownik Katedry i Zakładu Historii Słowiańszczyzny i Europy Wschodniej UW; 1958-1966 prodziekan i dziekan Wydziału Historycznego UW; 1975-1981 dyrektor Instytutu Krajów Socjalistycznych PAN, przewodniczący Komisji Historycznej Polsko-Radzieckiej PAN; członek PZPR; od 1983 r. członek Krajowej Rady Towarzystwa Przyjaźni Polsko-Radzieckiej. Opublikował m.in.: Działalność narodnictwa rosyjskiego w latach 1878-1881, Wrocław 1960; Siedmiogród a Polska 1576-1613, Warszawa 1967; Historia Rosji, Wrocław 1969; Dzieje Rosji 1801-1917, Warszawa 1971; Historia Mongolii, Wrocław 1981; Historia powszechna 1789-1918, Warszawa 1981; Historia powszechna 1492-1648, Warszawa 1991.
}

${ }^{17}$ B. Nagay, Wspomnienia..., k. 19.

18 Tamże, k. 16, 27. 
Chirurgicznej pod kierunkiem Stanisława Nowickiego ${ }^{19}$, a później Kazimierza Dębickiego ${ }^{20}$. Dzięki pracy w klinice, której oddziały obejmowały szeroko rozumianą chirurgię (ogólna i traumatologiczna, urologia, torakochirurgia), Nagay mógł uczyć się od doświadczonych medyków i szybko zdobywać wiedzę teoretyczną oraz biegłość chirurgiczną. To właśnie tam przeprowadził swoją pierwszą samodzielną operację, którą była appendektomia (usunięcie wyrostka robaczkowego). W październiku 1951 roku otrzymał wezwanie na komisję wojskową i skierowanie do Szkoły Oficerskiej. Po odbyciu trzymiesięcznego przeszkolenia, po którym oceniono go m.in. jako aspołecznego, planowano skierować lekarza do pułku czołgów w Trzebiatowie, co spotkało się z jego zdecydowanym sprzeciwem. Wkrótce okazało się, że jeden z kolegów, który otrzymał przydział do szpitala wojskowego w Koszalinie, nie chciał pracować „w jakiejś dziurze”, toteż Nagay zamienił się z nim i w ten sposób znalazł się w 118 Wojskowym Szpitalu Garnizonowym w Koszalinie. Także jego małżonka rozpoczęła pracę w tym mieście - była organizatorem Poradni dla Dzieci (w mieście nie było dotychczas żadnego lekarza pediatry). Wobec dużych braków kadrowych władze miasta same zaoferowały młodemu małżeństwu z dziećmi trzypokojowe mieszkanie nieopodal katedry. Służba w wojsku wiązała się z dodatkową koniecznością wyjazdów na poligony ze szpitalem polowym, co było uciążliwe dla rodziny, ale pozwalało na styczność ze szczególnymi przypadkami rannych. W szpitalu tym Nagay pracował do 1955 roku, dorabiając również na dyżurach w pogotowiu ratunkowym. W tym czasie nazwisko Nagay stało się w Koszalinie rozpoznawalne, a rodzina mogła żyć na stosunkowo dobrym poziomie.

W ramach procesu odwilży szpital wojskowy stał się szpitalem cywilnym, a Nagay po pięciu latach służby został zwolniony do cywila i rozpoczął pracę w Szpitalu Miejskim w Koszalinie, a kiedy po kolejnej reorganizacji powstał Oddział Chirurgii Ogólnej na terenie dawnego szpital wojskowego, znalazł tam swoje miejsce. W 1959 roku, po zdobyciu tytułu specjalisty z chirurgii ogólnej

${ }^{19}$ Tamże, k. 32. Stanisław Nowicki (1893-1972), chirurg, pionier chirurgii naczyniowej, 1948 r. prof. nadzw., kierownik I Katedry i Kliniki Chirurgicznej Akademii Lekarskiej w Gdańsku, kierownik I Kliniki Chirurgicznej Akademii Medycznej w Poznaniu, wykładowca chirurgii na Uniwersytecie Jagiellońskim; 1953-1955 prorektor Akademii Medycznej w Poznaniu; autor m.in. monografii Choroby tętnic kończyn.

${ }^{20}$ Kazimierz Dębicki (1900-1977), chirurg, 1949 r. prof. Akademii Medycznej w Gdańsku; 1960-1962 prezes Zarządu Głównego Towarzystwa Chirurgów Polskich; członek honorowy Polskiego Towarzystwa Lekarskiego, Europejskiego Towarzystwa Chirurgii Sercowo-Naczyniowej, Międzynarodowego Towarzystwa Proktologicznego; autor ponad 70 prac naukowych dotyczących chirurgii nowotworów, jamy brzusznej, klatki piersiowej oraz chirurgii naczyń oraz serca. 
II stopnia, objął stanowisko zastępcy ordynatora. To właśnie w tym szpitalu Nagay podczas operacji złamania uda wymyślił i opracował nowy model prowadnicy do gwoździ śródszpikowych Küntschera, dzięki czemu udało mu się skrócić operację do 35 min (wcześniejsza operacja trwała ponad dwie godziny) ${ }^{21}$.

W 1964 roku po obronie rozprawy Badania doświadczalne nad możliwościa powstawania stanów trombolitycznych $w$ przypadkach stosowania penicyliny krystalicznej i penicyliny-depot uzyskał tytuł doktora nauk medycznych w Akademii Medycznej w Gdańsku. W tym samym roku Nagay przeprowadził się do Szczecina, otrzymując zatrudnienie w II Klinice Chirurgii Ogólnej Pomorskiej Akademii Medycznej na stanowisku starszego asystenta, a następnie adiunkta. To właśnie w Szczecinie Nagay ukierunkował swoje zainteresowania na chirurgię ręki - już wtedy widział potrzebę wyodrębnienia z chirurgii ortopedycznej i ogólnej węższej specjalności22 ${ }^{22}$ Dlatego też po objęciu w 1977 roku kierownictwa nad II Kliniką Chirurgii Ogólnej w Instytucie Chirurgii PAM, po pięciu latach utworzył z niej Klinikę Chirurgii Ogólnej i Chirurgii Ręki PAM. W tym samym czasie zainicjował wprowadzenie w klinice ostrych dyżurów dla urazów ręki, co było nie tylko wyrazem jego zawodowej pasji, ale także istotnym krokiem w rozwoju chirurgii urazowej i naprawczej ręki w Polsce. Jako doświadczony medyk i mentor przyszłych chirurgów obejmował nad nimi szczególną pieczę, angażując się w rozwój specjalizacji z chirurgii ręki nie tylko lokalnie, ale także w wymiarze ogólnopolskim ${ }^{23}$.

Jednym z jego osiągnięć, które stało się kamieniem milowym w rozwoju chirurgii ręki, była pierwsza na Pomorzu Zachodnim udana retransplantacja ręki u radzieckiego robotnika pracującego w Szczecinie (przy rozładunku dostarczonych z ZSRR części domów tzw. Leningradów). Za to osiągnięcie chirurg został zresztą odznaczony Złotą Honorową Odznaką Towarzystwa Przyjaźni Polsko-Radzieckiej ${ }^{24}$.

${ }^{21}$ Szerzej na temat gwoździa śródszpikowego Küntschera: R.M. Molina, D.V. Vilamala, A.L. Garcia, P. Guirro, F.M. Lopez, A Technical Note for extracting an Incarcerated Femoral Kuntscher Nail, „Journal of ortopaedic case reports” 2016, nr 6 (3).

22 Relacja Leszka Nagaya w zbiorach autorów.

${ }^{23}$ B. Nagay, Z. Deskur, W sprawie specjalizacji w zakresie chirurgii ręki, w: XXXI Sympozjum Sekcji Chirurgii Ręki Polskiego Towarzystwa Ortopedycznego i Traumatologicznego, Gdańsk/ Jurata 16-17 maja 1997. Streszczenia, Gdańsk 1997, s. 37.

${ }^{24}$ Relacja Leszka Nagaya w zbiorach autorów. 
W 1967 roku Nagay został przyjęty do Sekcji Chirurgii Ręki, którą utworzono dwa lata wcześniej w Polskim Towarzystwie Ortopedycznym i Tramatologicznym. W 1977 roku, w miejsce sekcji, powołano Polskie Towarzystwo Chirurgii Ręki, którego prezesem został Władysław Manikowski ${ }^{25}$.

Stopień doktora habilitowanego Nagay uzyskał w 1974 roku na podstawie pracy Badania doświadczalne $i$ kliniczne nad możliwościa zastosowania pograżonych wszczepów w chirurgii naprawczej ścięgien ${ }^{26}$, w której analizował zastosowanie pasm skóry jako wszczepów do operacji naprawczych ścięgien ręki. Był to istotny krok w przywróceniu sprawności ręki w przypadku uszkodzenia jej ścięgien. Rok później otrzymał stanowisko docenta, w 1983 objął kierownictwo I Kliniki Chirurgii Ogólnej, a w 1986 roku otrzymał stanowisko profesora nadzwyczajnego PAM.

$\mathrm{Na}$ początku lat osiemdziesiątych bliżej zainteresowała się nim Służba Bezpieczeństwa, która zbierała informacje o lekarzu już w czasie jego pobytu w Koszalinie ${ }^{27}$. Nagay był rozpracowywany od czerwca 1982 r. w ramach tzw. sprawy operacyjnego sprawdzania o kryptonimie „Odwiedziny”, badającej kontakty obywatela Szwecji Gunnara Andersona, który, jak policzono, w ciągu 10 lat przyjechał do Polski 71 razy, przywożąc tzw. dary, w tym przede wszystkim leki, wyposażenie medyczne i ubrania. Nagaya uznano za jeden z jego najbliższych kontaktów w Polsce, a sprawę opisano jako „utrzymywanie kontaktów o niewyjaśnionym charakterze przez obywateli PRL zatrudnionych w ochranianych obiektach z obywatelami krajów kapitalistycznych" 28 . Policję polityczną interesowały także rewizyty polskich lekarzy w Szwecji organizowane przez Anderssona. Ostatecznie nie stwierdzono wrogiej działalności Szweda, ale Nagaya rozpracowywano dalej w ramach szerszych spraw „Lancet” i „Esculap”.

Zimą 1984 roku SB pozyskała Nagaya do współpracy w charakterze konsul$\operatorname{tanta}^{29}$. Wydaje się, że jego kontakty z policją polityczną służyły przede wszystkim

${ }^{25}$ Z. Deskur, A. Deskur, Działalność naukowa i zawodowa zespołu I Kliniki Chirurgii Ogólnej i Chirurgii Ręki Pomorskiego Uniwersytetu Medycznego w latach 1983-2005, Szczecin 2017, s. 11.

${ }^{26}$ B. Nagay, Badania doświadczalne i kliniczne nad możliwościa zastosowania pogrążonych wszczepów w chirurgii naprawczej ścięgien, Szczecin 1974.

${ }^{27}$ Rozpracowywano go wówczas jako kandydata na współpracownika w latach 1960-1962 i ponownie w Szczecinie w latach 1969-1972.

28 AIPN Sz sygn. 0011/1350, Sprawa Operacyjnego Sprawdzenia „Odwiedziny”.

${ }^{29}$ W grudniu 1984 r. Nagay został zarejestrowany jako konsultant SB o pseudonimie „Atos”. Informacje przekazywał ustnie, początkowo raz w miesiącu, później rzadziej, z czego sporządzano notatki. Nie pobierał wynagrodzenia i nie był wykorzystywany w tzw. kombinacjach 
do przekonania władz o konieczności wsparcia szczecińskiej chirurgii, a w końcu lat 80. podjęcia pilnych działań dla ratowania jej ze stanu głębokiej zapaści. Przykładowo wskazywał na zbyt duże obciążenie bloku operacyjnego PSK 1 (chirurdzy z ośmiu klinik mieli do dyspozycji pięć sal operacyjnych), a w związku z tym konieczność budowy nowego bloku. W sierpniu 1985 roku na prośbę SB opracował analizę funkcjonowania klinik zabiegowych w PSK1, wskazując m.in., że umieszczenie w szpitalu planowanym na 320 łóżek niemal dwukrotnie większej liczby pacjentów powoduje niewydolność funkcjonowania jednostki, w tym pralni, kuchni, kotłowni, częste awarie prądu i permanentne niedogrzanie nawet bloku operacyjnego. Wskazywał również na braki leków i płynów do kroplówek, określając sytuację w tym ostatnim zakresie jako dramatyczną, podobnie jak niedobory kadrowe wśród pielęgniarek i salowych oraz trudności w zatrudnieniu młodych lekarzy. Domagał się również doposażenia bloku w instrumenty. Specyfikę pracy w tamtym okresie najlepiej oddaje informacja o niebezpieczeństwie występującym na Oddziale Reanimacji (znajdował się nad kotłownią), który był do tego stopnia zadymiony, że stężenia tlenku i dwutlenku węgla przekraczały normy czterdziestokrotnie ${ }^{30}$.

W 1985 roku Nagay przedstawił projekt zmian w organizacji Instytutu Chirurgii PAM, który zakładał, że III Klinika Chirurgii Ogólnej, którą kierował doc. Marian Borowski-Beszta ${ }^{31}$, zostałaby włączona do ZOZ-u onkologicznego na Golęcinie, specjalizującego się w chirurgii onkologicznej. Jednocześnie Klinika Chirurgii Klatki Piersiowej i Naczyń, którą kierował prof. Seweryn Wiechowski³2,

operacyjnych. Planowano wykorzystać go do „wpływania na decyzje rady instytutu, rady wydziału i senatu zgodnie z przyjętymi kierunkami”. Współpracę ze względu na wiek i liczne obowiązki profesora oceniano jako pasywną, niemniej z zadowoleniem przyjęto zwolnienie ze stanowiska ordynatora Staniewicza w 1987 r. Według definicji przyjętej przez IPN konsultant to „kategoria osobowego źródła informacji, współpracownik SB zaangażowany ze względu na swoje umiejętności naukowe lub/i fachowe, pozycję naukową lub społeczną, którego zadaniem było sporządzanie ekspertyz i analiz na podstawie materiałów dostarczonych przez SB, dotyczących wskazanego zagadnienia lub środowiska [...]. W praktyce operacyjnej SB jako konsultantów rejestrowano również «zwykłych» współpracowników, gdy zaistniała tego proceduralna potrzeba" (np. członków partii), https://inwentarz.ipn.gov.pl/slownik?znak=K (dostęp 15.10.2017).

${ }^{30}$ AIPN Sz, sygn. 52575/I, Problemy pracy usługowej niektórych klinik PSK-1, źródło „Atos”, k. $52-55$.

${ }^{31}$ Marian Borowski-Beszta (1926-2011), lekarz chirurg; absolwent AM w Krakowie; 1978-1981 dziekan Wydziału Lekarskiego PAM; 1984-1996 kierownik Kliniki Chirurgii Ogólnej; prof. nadzw. PAM.

32 Seweryn Wiesław Wiechowski (ur. 1935), lekarz chirurg i kardiochirurg prof.; absolwent PAM w Szczecinie; pracownik II Kliniki Chirurgii PAM; 1972-1987 kierownik Kliniki Chirurgii 
miała zostać przeniesiona na Pomorzany, zaś na jej miejsce powstałaby Klinika Traumatologii. I i II Klinika Chirurgii Ogólnej pozostałyby bez zmian - PAM zyskałaby 80 łóżek, ale straciłaby jedną klinikę chirurgii ogólnej. Pomysły te natrafiły jednak na duży opór.

Jesienią 1986 roku rozważano instytucjonalne wyodrębnienie chirurgii naczyniowej. Rada Instytutu zdecydowała jednak, że chorych naczyniowo operować będą kliniki ogólnochirurgiczne przy udziale doc. Grzegorza Szumiłowicza i jego asystentów. Grupa ta miała przejść do III Kliniki i tylko w zakresie przychodni i konsultacji zajmować się chirurgią naczyniową. Szumiłowicz odwołał się od tej decyzji do rektora i KW PZPR, gdzie uzyskał zapewnienie, że na terenie III Kliniki utworzona zostanie placówka naczyniowa. Niemniej ze względu na bardzo liczne konflikty personalne i wzajemnie blokujących się pracowników samodzielnych, sprawa pozostała nierozstrzygnięta. Jednym z kolejnych pomysłów jej rozwiązania była propozycja Nagaya, aby w Gorzowie utworzyć filię PAM i tam umożliwić Szumiłowiczowi samodzielne prowadzenie chirurgii naczyniowej na stanowisku ordynatora. Wobec niechęci władz uczelni, które wskazywały na nieopłacalność tworzenia filii, także to rozwiązanie upadło, a w Gorzowie zatrudniono ordynatora z Łodzi. Szumiłowicz pozostał zaś na stanowisku zastępcy kierownika kliniki.

Skalę zapaści służby zdrowia w końcu istnienia PRL pokazuje informacja Nagaya z października 1987 roku: „coraz częściej zdarzają się przypadki że lekarze są bezradni wobec niektórych chorych młodych wiekiem, którzy z powodu braku leków są w zasadzie skazani na śmierć, przy czym lekarze mają świadomość, że są na Zachodzie leki mogące doprowadzić do wyleczenia, jednakże nawet o nich nie wspominają, gdyż koszty indywidualnego zakupu są poza możliwościami przeciętnego obywatela, np. 40 dolarów za ampułkę"33.

Nagay słynął z umiejętności współpracy z zakładami pracy w regionie, których dyrekcje potrafił przekonać do inwestowania w klinikę. Dzięki jego osobistym kontaktom jednostkę wspierały i wyposażały największe zakłady Pomorza Zachodniego. Inżynierowie stoczni i zakładów „Polmo” wykonywali prototypy

Klatki Piersiowej i Naczyń PAM; 1984-1987 prorektor PAM ds. nauki; 1990-1996 rektor PAM; 1987-2002 kierownik Kliniki Kardiochirurgii PSK 1 w Szczecinie; 2002-2005 kier. Kliniki Kardiochirurgii w PSK 2; działacz Szczecińskiego Klubu Katolików; od IX 1980 członek Solidarności, przewodniczący KZ PAM; 1986-1990 członek Prymasowskiej Rady Społecznej; od 2005 r. na emeryturze.

${ }^{33}$ AIPN, 52575/I, Notatka stużbowa z 24 X 1987 r., k. 62. 
narzędzi i implantów według pomysłu i idei profesora, stocznia zaś ufundowała zakup japońskiego fiberoskopu za 9 tys. dolarów.

W 1988 roku doszło do zmiany nazwy kliniki, którą kierował Nagay, na Klinikę Chirurgii Ogólnej i Chirurgii Ręki. Jego szerokie zainteresowania naukowe obejmowały wiele dziedzin medycyny, do których zaliczały się chirurgia jamy brzusznej czy chirurgia urazowa, które praktykował już na początku swojej ponadpięćdziesięcioletniej kariery, jednak najbardziej spektakularnym i najszerszym obszarem zainteresowania pozostawała chirurgia ręki, która przyniosła mu uznanie nie tylko w Polsce (przez dwie kadencje pełnił funkcję prezesa Sekcji Chirurgii Ręki Polskiego Towarzystwa Ortopedycznego i Traumatologicznego), ale i na świecie. Nagay, jako pierwszy Polak w historii, otrzymał od Światowej Federacji Chirurgii Ręki tytuł Pioniera Chirurgii Ręki na zjeździe w Vancouver w 1998 roku $^{34}$.

W ciągu kilkudziesięciu lat pracy naukowej Nagay osiągnął znaczącą pozycję i liczący się dorobek naukowy, obejmujący ponad 100 publikacji. Były to nie tylko prace pozwalające zdobywać kolejne stopnie naukowe, ale także artykuły w czołowych czasopismach medycznych oraz aktywne uczestnictwo w krajowych i zagranicznych konferencjach, zjazdach, sympozjach ${ }^{35}$.

${ }^{34}$ IFSSH Pioneers of Hand Surgery, $12^{\text {th }}$ Triennial Congress of the International Federation of Societies for Surgery of the Hand, New Delhi, India, $4^{\text {th }}-8^{\text {th }}$ March, 2013, http://www.ifssh.info/ pioneerbooklet2016.pdf (dostęp 6.06.2017).

${ }^{35}$ Jednym z ważniejszych było XX Sympozjum Sekcji Chirurgii Ręki PTOiTr (8-10.09.1984 r.), któremu przewodniczył B. Nagay. Wygłoszono wówczas kilka referatów, które następnie opublikowano. Por.: B. Nagay, M. Mikee, J. Chojnacki, Z. Deskur, K. Szlęzak, Sprawność chwytna ręki po zmodyfikowanej operacji Parksa w nieodwracalnych uszkodzeniach nerwu łokciowego, „Polish Hand Surgery” 1984, nr 20 (2), s. 59-61. Por. także: B. Nagay, Z. Deskur, A. Kucharski, S. Jaroszewicz, K. Szlęzak, Uszkodzenie dtugiego zginacza kciuka, „Polish Hand Surgery” 1985, nr 1-5, s. 99; B. Nagay, H. Stanisławski, Z. Deskur, Uszkodzenia urazowe wątroby - wczesne i odległe wyniki leczenia chirurgicznego, w: 56 Zjazd Towarzystwa Chirurgów Polskich [Lublin 8-11 września 1993]: Streszczenia T. 1, Lublin 1993; B. Nagay, Z. Deskur, H. Staniewski, Ropnie wątroby - ocena chirurgicznego leczenia ropni wątroby, w: 56 Zjazd Towarzystwa Chirurgów Polskich [ Lublin 8-11 września 1993], Streszczenia T. 3, Lublin 1993; H. Staniewski, B. Nagay, Z. Deskur, A. Żyluk, J. Chojnacki, Porównawcza ocena zespoleń mechanicznych i klasycznych w chirurgii przewodu pokarmowego, Fundacja Polski Przegląd Chirurgiczny, Warszawa 1995, s. 80-82; A. Żyluk, B. Nagay, P. Prowans, Reasons of poor reponse to the treatment of posttraumatic algodystrophy, w: 57 Zjazd Towarzystwa Chirurgów Polskich [Szczecin 6-9 września 1955], Streszczenia, s. 201; B. Nagay, Petardowe uszkodzenia rąk, w: XXVIII Zjazd Polskiego Towarzystwa Ortopedycznego i Traumatologicznego, Szczecin 1990; wygłoszona na II Zjeździe Unii Polskich Towarzystw Chirurgicznych praca: Z. Deskur, B. Nagay, S. Jaroszewicz, P. Prowans, M. Bednarski, Mnogie obrażenia ciata u chorych przyjętych podczas ostrego dyżuru; B. Nagay, Z. Deskur, Postępujący pourazowy przykurcz mięśni zginaczy palców rąk, „Chirurgia Narządu 
Z dziedziny chirurgii ręki na szczególną uwagę zasługują publikacje poświęcone pionierskiemu, na skalę kraju, dwuetapowemu leczeniu przykurczu Dupuytrena $^{36}$. To także prace poświęcone nowatorskim metodom leczenia obrażeń rąk, rekonstrukcji ścięgien oraz operacji naprawczych ręki ${ }^{37}$. Jego działalność na polu chirurgii jamy brzusznej obejmowała wiele zagadnień - chirurgię wątroby, przełyku, żołądka. Dużą aktywność Nagay przejawiał w dziedzinie chirurgii urazowej. Opublikował 13 prac z tego zakresu, w tym monografię opartą na obszernym materiale 64 tys. historii chorób i 1170 urazów czaszkowo-mózgowych, która została przedstawiona na 42. Zjeździe Chirurgów w Gdańsku w 1964 roku $^{38}$.

Bolesław Nagay to nie tylko utalentowany naukowiec, ale także nauczyciel akademicki, w pewnych wymiarach autorytet. Pod swoimi skrzydłami wykształcił wielu zasłużonych i cenionych lekarzy, był promotorem licznych prac doktorskich. Na szczególną uwagę zasługują: Tadeusz Sokołowski i Jego Szkoła Chirurgiczna autorstwa Witolda Brzezińskiego, Wplyw miejscowo podawanego preparatu Polcortolon na wytrzymatość zdrowych ścięgien Achillesa szczura z uwzględnieniem różnych prędkości rozciagania (Piotr Prowans), Ocena wyników leczenia algodystrofii Sudecka (Andrzej Żyluk), Odległe wyniki leczenia złamań kości podudzi w materiale Szpitala Rejonowego w Kostrzynie n/O w latach 1984-1993 (Andrzej Knut), Ocena wartości prostego zeszycia przedziurawionego

Ruchu i Ortopedia Polska" 1997, supl. 1, s. 169-172. Szerzej o działalności naukowej kliniki: Z. Deskur, A. Deskur, Działalność naukowa...

${ }^{36}$ B. Nagay, Two-stage operation, w: Dupuytren's disease-biology and treatment, red. R.M. McFerlane, D.A. Grouther, M.H. Flint, wyd. 1, London 1990, s. 337-340; B. Nagay, Z. Deskur, P. Prowans, M. Bednarski, 30 lat operacyjnego leczenia przykurczu Dupuytrena, „Polish Hand Surgery” 1998, nr 2, s. 37-40; B. Nagay, Z. Deskur, Przykurcz Dupuytrena: etiopatogeneza - epidemiologia - klinika, „Polski Przegląd Chirurgiczny” 1992, nr 64 (2), s. 128-134; B. Nagay, H. Staniewski, Z. Deskur, M. Bednarski, Otwarta fasciotomia jako zabieg samodzielny lub wstępna operacja ciężkich postaci przykurczu Dupuytrena, „Polish Hand Surgery” 1993, nr 1 (18), s. 17-20.

${ }^{37}$ P. Prowans, B. Nagay, A. Żyluk, W. Jagielski, Z. Niedźwiedź, I. Walaszek, The use greater omentum as a reconstructive material - 14 years of experience, „Magyar Traumatologia, Ortopedia, Kezsebeszet, Plasztikai Sebeszet” 2004, nr 2 (47), s. 262; P. Prowans, Z. Deskur, W. Brzeziński, B. Nagay, Zaopatrywanie pourazowych ubytków tkanek w obrębie kończyny górnej za pomoca sieci większej, „Polski Przegląd Chirurgiczny” 1998, nr 1 (70), s. 54-58; Z. Deskur, B. Nagay, Kompleksowa ocena niektórych metod operacyjnych odtwarzajacych czynność ręki po pourazowym nieodwracalnym uszkodzeniu nerwów promieniowego i łokciowego, „Chirurgia Narządu Ruchu” 1997, supl. 1, s. 95-98; B. Nagay, Z. Deskur, Postępujący pourazowy przykurcz mięśni zginaczy palców rąk, „Chirurgia Narządu Ruchu” 1997, supl. 1, s. 169-172.

${ }^{38}$ P. Szlarb, P. Prowans, Wspomnienia. Prof. dr hab. n. med. Bolesław Nagay 1926-2014, „Biuletyn Informacyjny Pomorskiego Uniwersytetu Medycznego" 2014, nr 1 (83), s. 38. 
wrzodu trawiennego żoładka lub dwunastnicy na tle operacji definitywnych (Jerzy Janik). Nagay był także twórcą podręczników dla studentów i lekarzy, m.in. Kompendium Chirurgii Ogólnej ${ }^{39}$ czy Chirurgia ręki ${ }^{40}$, które stanowiły podstawę wiedzy kształcących się studentów, a także Zarysu postępowania w świeżych obrażeniach rą $k^{41}$, w którym opisał nowoczesne postępowanie w świeżych uszkodzeniach ścięgien.

Mimo że Bolesław Nagay zapisał się w historii medycyny, wspomnieć trzeba, że nie zawsze odnosił wyłącznie sukcesy. Zdarzały się też niepowodzenia. Sam wspominał przypadek rozpoznania ropnia okolicy pośladkowej, który po nacięciu okazał się zropiałym tętniakiem tętnicy pośladkowej i mimo szybkiego opanowania krwotoku doszło do zatrzymania akcji serca i śmierci pacjenta. To zdarzenie wywołało w młodym chirurgu ogromny wstrząs. Zapamiętał na całe życie sentencję profesora Kornela Michejdy: „Powodzenia chirurgów oświetla słońce, a niepowodzenia przykrywa ziemia" ${ }^{{ }^{42}}$. W 1996 roku przeszedł na emeryturę, ale z uwagi na doświadczenie i autorytet pozostawał do 2001 roku na stanowisku profesora nadzwyczajnego PAM na ćwierć etatu jako biegły Zakładu Medycyny Sądowej $\mathrm{PAM}^{43}$. Udzielał również konsultacji lekarskich w prywatnym gabinecie. Po jego odejściu kliniką kierował Zbigniew Deskur ${ }^{44}$.

Od 1960 roku należał do Stronnictwa Demokratycznego, w 1989 wstąpił do „Solidarności” (w całej klinice członkami związku zostały tylko dwie osoby), później zaś był członkiem Unii Wolności. Angażował się w organizowanie pomocy charytatywnej dla mniejszości polskiej we Lwowie (w tym polskiej szkoły). Zmarł 8 stycznia 2014 roku.

Bolesław Nagay wpisał się na stałe do historii medycyny nie tylko ze względu na nieprzeciętny życiorys, szczególne osiągnięcia naukowe i kilkadziesiąt lat pracy przy stole operacyjnym, ale również ze względu na podjęcie pracy na Pomorzu Zachodnim, w czasie gdy dopiero organizowano służbę zdrowia w okresie powojennym. Jego nieprzeciętne zdolności spowodowały, że stał się ojcem założycielem szczecińskiej szkoły chirurgii ręki.

\footnotetext{
${ }^{39}$ B. Nagay, Kompendium Chirurgii Ogólnej, Szczecin 1998.

${ }^{40}$ B. Nagay, Chirurgia ręki, Warszawa 1996.

${ }^{41}$ B. Nagay, Zarys postępowania w świeżych obrażeniach rąk, Szczecin 1987.

${ }^{42}$ B. Nagay, Wspomnienia..., k. 32.

${ }^{43}$ Archiwum Pomorskiego Uniwersytetu Medycznego, Akta personalne Bolesław Nagay.

${ }^{44}$ Z. Deskur, A. Deskur, Działalność naukowa..., s. 9.
} 


\section{Bibliografia}

\section{Źródla archiwalne}

Archiwum Pomorskiego Uniwersytetu Medycznego w Szczecinie

Akta Personalne Bolesław Nagay.

Instytut Pamięci Narodowej w Szczecinie

AIPN Sz sygn. 0011/1350; AIPN Sz, sygn. 52575/I.

\section{Wspomnienia niepublikowane}

Nagay B., Wspomnienia starego chirurga, mps udostępniony przez Leszka Nagaya.

\section{Prasa}

„Gazeta Lwowska” 1937 r.

\section{Relacje}

Relacja Leszka Nagaya w zbiorach autorów.

\section{Wybór publikacji Bolesława Nagaya}

Deskur Z., Nagay B., Kompleksowa ocena niektórych metod operacyjnych odtwarzajacych czynność ręki po pourazowym nieodwracalnym uszkodzeniu nerwów promieniowego i łokciowego, „Chirurgia Narządu Ruchu” 1997, supl. 1.

Nagay B., Badania doświadczalne i kliniczne nad możliwościa zastosowania pogrążonych wszczepów w chirurgii naprawczej ścięgien, Szczecin 1974.

Nagay B., Chirurgia ręki, Warszawa 1996.

Nagay B., Kompendium Chirurgii Ogólnej, Szczecin 1998.

Nagay B., Petardowe uszkodzenia rą, w: XXVIII Zjazd Polskiego Towarzystwa Ortopedycznego i Traumatologicznego, Szczecin 1990.

Nagay B., Two-stage operation, w: Dupuytren's disease-biology and treatment, red. R.M. McFerlane, D.A. Grouther, M.H. Flint, wyd. 1, London 1990.

Nagay B., Zarys postępowania w świeżych obrażeniach rąk, Szczecin 1987.

Nagay B., Deskur Z., Postępujący pourazowy przykurcz mięśni zginaczy palców rąk, „Chirurgia Narządu Ruchu” 1997, supl. 1.

Nagay B., Deskur Z., Przykurcz Dupuytrena: etiopatogeneza-epidemiologia - klinika, „Polski Przegląd Chirurgiczny” 1992, nr 2 (64).

Nagay B., Deskur Z., W sprawie specjalizacji w zakresie chirurgii ręki, w: XXXI Sympozjum Sekcji Chirurgii Ręki Polskiego Towarzystwa Ortopedycznego i Traumatologicznego, Gdańsk/Jurata 16-17 maja 1997. Streszczenia. Gdańsk 1997.

Nagay B., Deskur Z., Kucharski A., Jaroszewicz S., Szlęzak K., Uszkodzenie długiego zginacza kciuka, „Polish Hand Surgery” 1985, nr 1-5.

Nagay B., Deskur Z., Prowans P., Bednarski M., 30 lat operacyjnego leczenia przykurczu Dupuytrena, „Polish Hand Surgery” 1998, nr 2. 
Nagay B., Deskur Z., Staniewski H., Ropnie wątroby - ocena chirurgicznego leczenia ropni wątroby, w: 56 Zjazd Towarzystwa Chirurgów Polskich [Lublin 8-11 września 1993], Streszczenia T. 3, Lublin 1993.

Nagay B., Mikee M., Chojnacki J., Deskur Z., Szlęzak K., Sprawność chwytna ręki po zmodyfikowanej operacji Parksa w nieodwracalnych uszkodzeniach nerwu łokciowego, „Polish Hand Surgery” 1984, nr 2 (20).

Nagay B., Staniewski H., Deskur Z., Uszkodzenia urazowe watroby - wczesne i odległe wyniki leczenia chirurgicznego, w: 56 Zjazd Towarzystwa Chirurgów Polskich [Lublin 8-11 września 1993]: Streszczenia T. 1, Lublin 1993.

Nagay B., Staniewski H., Deskur Z., Bednarski M., Otwarta fasciotomia jako zabieg samodzielny lub wstęna operacja ciężkich postaci przykurczu Dupuytrena, „Polish Hand Surgery" 1993, nr 1 (18).

Prowans P., Deskur Z., Brzeziński W., Nagay B., Zaopatrywanie pourazowych ubytków tkanek w obrębie kończyny górnej za pomoca sieci większej, „Polski Przegląd Chirurgiczny" 1998, nr 1 (70).

Prowans P., Nagay B., Żyluk A., Jagielski W., Niedźwiedź Z., Walaszek I., The use greater omentum as a reconstructive material - 14 years of experience, „Magyar Traumatologia, Ortopedia, Kezsebeszet, Plasztikai Sebeszet” 2004, nr 2 (47), s. 262.

\section{Opracowania i artykuły}

Allen A., Fantastyczne laboratorium Doktora Weigla. Lwowscy uczeni, tyfus i walka z Niemcami, Wołowiec 2016.

Deskur Z., Deskur A., Działalność naukowa i zawodowa zespołu I Kliniki Chirurgii Ogólnej i Chirurgii Ręki Pomorskiego Uniwersytetu Medycznego w latach 1983-2005, Szczecin 2017.

Dwudziestolecie nauki polskiej na Pomorzu Szczecińskim 1946-1966, red. L. Babiński, H. Lesiński, Szczecin-Poznań 1968.

Janiszewski L., Lesiński H., Rola i osiągnięcia nauk humanistycznych w procesach integracyjnych i kulturowych Pomorza Zachodniego w latach 1945-1985, w: Udział nauki i szkolnictwa wyższego w rozwoju Pomorza Zachodniego w latach 1945-1985, red. H. Lesiński, Szczecin 1986.

Lesiński H., Rozwój nauki i szkolnictwa wyższego w Szczecinie, „Przegląd Zachodniopomorski” 1975, z. 3-4.

Molina R.M., Vilamala D.V., Garcia A.L., Guirro P., Lopez F.M., A Technical Note for extracting an Incarcerated Femoral Kuntscher Nail, ,Journal of ortopaedic case reports" 2016, nr 3 (6). 
Nauka polska na Pomorzu Szczecińskim 1946-1956-1976: materiały z sesji naukowej zorganizowanej przez Szczecińskie Towarzystwo Naukowe w ramach obchodów XX-lecia STN i XXX-lecia powstania szkolnictwa wyższego w Szczecinie, red. H. Lesiński, Szczecin 1979.

Od Akademii Lekarskiej w stronę Uniwersytetu Medycznego: instytucja, red. J. Kojder, Szczecin 2008.

Powstawanie uczelni medycznej na Pomorzu Zachodnim: historia nauczania dziedzin medycyny w Pomorskiej Akademii Medycznej, red. J. Kojder, Szczecin 2008.

Rzepa T., Leoński J., O biografii i metodzie biograficznej, Poznań 1993.

Rzepa T., Leoński J., Szkice do portretów, Węgrowiec 1994.

Staniewski H., Nagay B., Deskur Z., Żyluk A., Chojnacki J., Porównawcza ocena zespoleń mechanicznych $i$ klasycznych $w$ chirurgii przewodu pokarmowego, Warszawa 1995.

Szlarb P., Prowans P., Wspomnienia. Prof. dr hab. n. med. Bolesław Nagay 1926-2014, „Biuletyn Informacyjny Pomorskiego Uniwersytetu Medycznego” 2014, nr 1 (83).

Ślepowroński T., Polska i wschodnioniemiecka historiografia Pomorza Zachodniego 1945-1970, Szczecin 2008 (mps w zbiorach autorów).

Zwyciężý tyfus: Instytut Rudolfa Weigla we Lwowie: dokumenty $i$ wspomnienia, red. Z. Stuchly, Wrocław 2001.

\section{Netografia}

IFSSH Pioneers of Hand Surgery, $12^{\text {th }}$ Triennial Congress of the International Federation of Societies for Surgery of the Hand, New Delhi, India, $4^{\text {th }}-8^{\text {th }}$ March, 2013, http://www.ifssh.info/pioneerbooklet2016.pdf (dostęp 6.06.2017).

Wykaz osób zatrudnionych w Instytucie prof. Rudolfa Weigla w latach niemieckiej okupacji Lwowa (lipiec 1941 - lipiec 1944), http://wow.eu/weigl/weiglowcy2013.pdf (dostęp 6.06.2017). 


\begin{abstract}
Abstrakt
Celem artykułu jest przedstawienie szkicu biograficznego jednej z wybitnych postaci szczecińskiej medycyny, nauczyciela całego pokolenia szczecińskich chirurgów, światowej klasy specjalisty chirurgii ręki, Bolesława Nagaya.

Pochodził ze Lwowa, gdzie w czasie wojny był karmicielem wszy w Instytucie Weigla. Był również żołnierzem Armii Krajowej. W końcu sierpnia 1945 roku wyjechał z rodzinnego miasta z transportem Teatru Polskiego. Rodzina zamieszkała początkowo u krewnych w Rozwadowie, a następnie udała się do Gdyni. Nagay rozpoczął studia na Wydziale Lekarskim Akademii Medycznej w Gdańsku. Po uzyskaniu absolutorium (w 1950 r.), ale jeszcze przed zaliczeniem siedmiu egzaminów dyplomowych, uzyskał pracę jako zastępca młodszego asystenta w I Klinice Chirurgicznej pod kierunkiem Stanisława Nowickiego, a później Kazimierza Dębickiego. Dzięki pracy w klinice, której oddziały obejmowały szeroko rozumianą chirurgię (ogólna i traumatologiczna, urologia, torakochirurgia), Nagay mógł uczyć się od doświadczonych medyków i szybko zdobywać wiedzę teoretyczną oraz biegłość chirurgiczną. Później pracował w 118 Wojskowym Szpitalu Garnizonowym w Koszalinie i Szpitalu Miejskim. W 1964 roku po obronie rozprawy Badania doświadczalne nad możliwościa powstawania stanów trombolitycznych w przypadkach stosowania penicyliny krystalicznej i penicyliny-depot uzyskał tytuł doktora nauk medycznych w Akademii Medycznej w Gdańsku. W tym samym roku Nagay przeprowadził się do Szczecina, gdzie został zatrudniony w II Klinice Chirurgii Ogólnej Pomorskiej Akademii Medycznej na stanowisku starszego asystenta, a następnie adiunkta. To właśnie w Szczecinie ukierunkował swoje zainteresowania na chirurgię ręki. Już wtedy widział potrzebę wyodrębnienia z chirurgii ortopedycznej i ogólnej węższej specjalności - chirurgii ręki. Dlatego też po objęciu w 1977 roku kierownictwa nad II Kliniką Chirurgii Ogólnej Pomorskiej Akademii Medycznej (PAM) w Instytucie Chirurgii PAM po pięciu latach utworzył z niej Klinikę Chirurgii Ogólnej i Chirurgii Ręki PAM.

Bolesław Nagay to nie tylko utalentowany naukowiec, ale także nauczyciel akademicki, w pewnych wymiarach autorytet. Pod swoimi skrzydłami wykształcił wielu zasłużonych i cenionych lekarzy. Angażował się w organizowanie pomocy charytatywnej dla mniejszości polskiej we Lwowie (w tym polskiej szkoły). Zmarł 8 stycznia 2014 roku.
\end{abstract}




\title{
Boleseaw Nagay (1926-2014). A Portrait of a Surgeon
}

\begin{abstract}
The article presents a biography of one of the most outstanding figures of the Szczecin medicine, a teacher of the whole generation of Szczecin surgeons, a world-class specialist in the surgery of the hand, Bolesław Nagay.

He came from Lviv, where during the war he was a host for lice at the Weigl Institute. He was also a soldier of the Home Army. At the end of August, 1945 he left Lviv together with the Polish Theatre. At the beginning he and his family lived in Rozwadów, next they went to Gdynia. At that time he started university studies at the Medical Academy in Gdańsk. After obtaining the certificate of completion of studies (1950) and before passing the seven diploma exams he was employed as a junior assistant's deputy at the First Surgical Clinic under the supervision of Stanisław Nowicki, and later Kazimierz Dębicki. Thanks to his work at the Clinic, which dealt with general surgery (traumatology, urology, cardiothoracic surgery), Nagay had the chance to learn from experienced doctors and acquire theoretical knowledge and surgical skills. Later he worked in the 118 Military Garrison Hospital in Koszalin and in the Town Hospital. In 1964 in Gdańsk he obtained the title of Doctor of Medicine, after defending the dissertation 'Experimental Research into the Possibility of Appearing Thrombolytic States Treated by Crystalline Penicillin and Depot-Penicillin (long-life medication)'. In the same year Nagay moved to Szczecin and was employed at the Second Clinic of General Surgery of the Pomeranian Medical Academy as a senior assistant, and later as an adjunct. it was in Szczecin where Nagay focused his attention on the surgery of the hand. From the very beginning he saw the need to isolate a narrower specialisation of orthopaedic surgery, the surgery of the hand. That is why in 1977 after becoming the head of the Second Clinic of General Surgery of the Pomeranian Medical Academy (PAM) Nagay transformed the Institute of Surgery of PAM into the Clinic of General Surgery and the Surgery of the Hand of PAM.

Nagay was not only a talented research worker, but also a university teacher and an authority. He educated many distinguished physicians. He committed himself to organising charity aid for the Polish minority in Lviv (including the Polish school). He died on January 8, 2014.
\end{abstract}

